Отримано: 1 березня 2018 р.

Прорецензовано: 5 березня 2018 р.

Прийнято до друку: 19 березня 2018 р.

e-mail: julian.rivage@gmail.com

DOI: $10.25264 / 2519-2558-2018-1(69) / 1-251-253$
Yuliia Lysanets, Olena Bieliaieva, Olena Pisotska. Professional medical discourse in british and american english: spelling differences. Наукові записки Національного університету «Острозька академія»: серія «Філологія». Острог : Вид-во НаУОА, 2018. Вип. 1(69), ч. 1, березень. С. 251-253.

\author{
Yuliia Lysanets, \\ Olena Bieliaieva, \\ Olena Pisotska,
}

Higher State Educational Establishment of Ukraine "Ukrainian Medical Stomatological Academy”, Poltava

\title{
PROFESSIONAL MEDICAL DISCOURSE IN BRITISH AND AMERICAN ENGLISH: SPELLING DIFFERENCES
}

The paper focuses on the features of medical terminology through the prism of differences in spelling of British and American English. The present research is the first scientific effort to synthesize and summarize the potential difficulties that may arise when working with medical discourse genres of British and American English. The main differences in spelling of British and American English have been outlined. The authors developed methodical recommendations for minimizing and avoiding errors in the English language writing by Ukrainian scholars. The authors emphasize the importance of following the consistency principle when writing for British or American audience. It is necessary to pay special attention to spelling features of British and American medical English when developing academic ESP syllabi at medical universities. The study of potential difficulties, which Ukrainian medical professionals may encounter in the process of producing medical discourse in British and American English, is important for developing relevant guidelines to eliminate possible mistakes and avoid misunderstanding in medical communication. It is crucial for medical professionals to be aware of peculiarities of British and American medical English in order to be understood and accepted in the modern English-speaking world. The analysis of potential challenges in producing medical discourse in British and American English is an important element for integration of Ukrainian researchers into the world community. The research will be useful for translation studies, teaching English as a second language, and developing multilingual competence of future doctors.

Key words: medical terminology, medical discourse, speech errors.

\section{Лисанець Юлія Валеріївна, Бєляєва Олена Миколаӥвна, \\ Пісоцька Олена Олександрівна,}

Вищий державний навчальний заклад Украйни «Украӥнська медична стоматологічна академія», м. Полтава

\section{ПРОФЕСІЙНИЙ МЕДИЧНИЙ ДИСКУРС У БРИТАНСЬКОМУ І АМЕРИКАНСЬКОМУ ВАРІАНТАХ АНГЛІЙСЬКОЇ МОВИ: ВІДМІННОСТІ У ПРАВОПИСІ}

У статті проаналізовано особливості медичної термінологї крізь призму відмінностей у правописі британської і американської англійської мови. Пропонована розвідка є першою науковою спробою синтезувати й узагальнити потенційні труднощі, які можуть виникнути при роботі з жанрами медичного дискурсу британського і американського варіантів англійської мови. Розроблено методичні рекомендації щзодо мінімізації й уникнення помилок в англомовному писемному мовленні украӥнських науковців.

Ключові слова: медччна термінологія, медичний дискурс, мовні помилки.

\section{Лисанец Юлия Валериевна, Беляева Елена Николаевна, Песоцкая Елена Александровна,}

Высшее государственное учебное заведение Украинь

«Украинская медицинская стоматологическая академия», г. Полтава

\section{ПРОФЕССИОНАЛЬНЫЙ МЕДИЦИНСКИЙ ДИСКУРС В БРИТАНСКОМ И АМЕРИКАНСКОМ ВАРИАНТАХ АНГЛИЙСКОГО ЯЗЫКА: ОТЛИЧИЯ В ПРАВОПИСАНИИ}

В статье проанализированы особенности медицинской терминологии сквозь призму различий в правописании британского и американского английского языка. Данное исследование является первой научной попьткой синтезировать и обобщить потенииальные трудности, которые могут возникнуть при работе с жанрами медицинского дискурса британского и американского вариантов английского языка. Разработаны методические рекомендации с иелью минимизации и избежания ошибок в англоязычной письменной речи украинских ученых.

Ключевые слова: медицинская терминология, медицинский дискурс, речевые ошибки.

The prevalence of English as not only the lingua franca, but as an important transmission medium of scientific knowledge in our time compels the professionals in all spheres of science and technology to render their research results in English in order to be understood and acknowledged. Internationalization of higher education raises a demand for effective training of students who will ultimately succeed in the wider English-speaking world [10]. However, conversational fluency does not guarantee the effective mastering of academic writing skills: it is necessary to acquire the so-called "academic literacy" in English as a global language in science and technology [9]. In order to achieve this objective, medical professionals are expected to be not only fluent in English, but also well-versed in academic style and standards. The major challenges in academic English vocabulary and grammar have already 
been discussed in our previous studies $[1 ; 2 ; 3 ; 4]$. We also focused upon potential errors in academic English spelling and punctuation $[5 ; 6 ; 7 ; 8]$. The present paper directs attention to the features of medical terminology through the prism of differences in spelling standards of British and American English.

The aim of the study is to outline major differences in spelling of British and American English and to develop methodical recommendations for minimizing and avoiding errors in the English language writing by Ukrainian scholars. The present study is the first scientific effort to synthesize and summarize the potential difficulties that may arise when working with medical discourse genres of British and American English, which renders the research relevant.

There are several areas in which British and American spelling are different [9]. British English tends to retain the spelling of words which it has absorbed from other languages (e.g., Latin), while American English has adapted the spelling to reflect the way that the words actually sound [9]. Tables 1, 2 represent the most widespread medical terms with Latin diphthongs "ae" and "oe" which are preserved in British English and reduced to "e" in the US.

Spelling differences in British and US English: vowels "ae" and " $\mathrm{e}$ "

Table 1

\begin{tabular}{|c|c|}
\hline $\mathrm{Br}$ & US \\
\hline$\underline{\text { aetiology }}$ & etiology \\
\hline anaemia & anemia \\
\hline anaesthetic & anesthetic \\
\hline caesarean & cesarean \\
\hline defaecation & defecation \\
\hline dyslipidaemia & dyslipidemia \\
\hline glycaemic & glycemic \\
\hline gynaecology & gynecology \\
\hline haemoglobin & hemoglobin \\
\hline haemorrhage & hemorrhage \\
\hline ischaemic & ischemic \\
\hline leukaemia & leukemia \\
\hline orthopaedic & orthopedic \\
\hline paediatric & pediatric \\
\hline
\end{tabular}

Spelling differences in British and US English: vowels "oe" and " $e$ "

\begin{tabular}{|c|c|}
\hline $\mathrm{Br}$ & US \\
\hline diarrhoea & diarrhẹa \\
\hline coeliac & celiac \\
\hline dyspnoea & dyspnea \\
\hline foetus & fetus \\
\hline manoeuvre & maneuver \\
\hline oedema & edema \\
\hline oesophagus & essophagus \\
\hline oestrogen & estrogen \\
\hline
\end{tabular}

Table 2

Another common challenge for non-native speakers of English consists in the choice of endings in certain terms, depending on the British/American context. Table 3 provides a list of words with endings "-re" (Br) / "-er" (US) and "-our" (Br) / "-or" (US).

Spelling differences in British and US English: endings "-re" and "-er"; "-our" and "-or"

Table 3

\begin{tabular}{|c|c|c|c|}
\hline$\underline{\mathrm{Br}}$ & $\underline{\mathrm{US}}$ & $\underline{\mathrm{Br}}$ & $\underline{\text { US }}$ \\
\hline centimetre & centimeter & behaviour & behavior \\
\hline centre & center & colour & color \\
\hline fibre & fiber & humour & humor \\
\hline lite & liter & labour & labor \\
\hline titre & titer & tumour & tumor \\
\hline
\end{tabular}

Yet another spelling difficulty may be encountered with endings "-ise" / "-ize" and "-yse" / "-yze" (Table 4).

Table 4

Spelling differences in British and US English: endings "-ise" and "-ize"; "-yse" and "-yze"

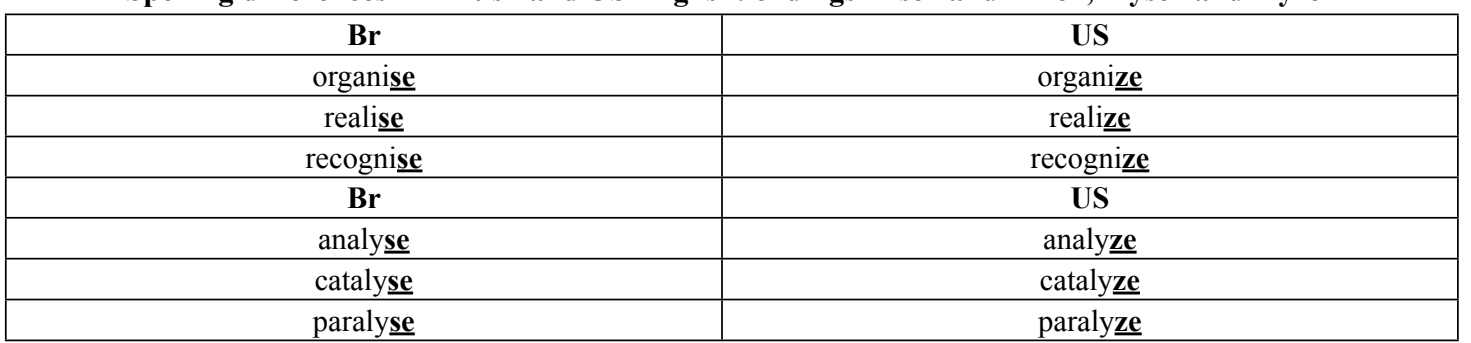


Most peer-reviewed academic journals have particular requirements regarding the British or American spelling. Therefore, it is crucial for medical professionals to follow the consistency principle, i.e., always to spell as the journal prefers - US or UK, - and never a mixture of styles [9]. Consistent spelling within the same piece of writing when writing for British or American audience is an essential prerequisite for scholars. By contrast, mixing British and American English in formal writing provides an impression of author's incoherence and illiteracy. Consequently, it can influence the reviewer's or editor's decision, and eventually result in paper's rejection. Therefore, it is necessary to pay special attention to spelling features of British and American medical English when developing academic ESP syllabi at medical universities.

The provided lists of lexical units are by no means exhaustive: they aim to structure the material under consideration and stipulate further development. The aforementioned material has already been integrated into the 1st edition of Medical English for Academic Purposes (by Yu. Lysanets, O. Bieliaieva, M. Melaschenko: in press), which largely focuses on improving the writing skills in British and American English.

We also suggest grouping the miscellaneous lexis of medicine and healthcare in British and American English as displayed in Table 5. The proposed system of organizing the material aims to facilitate memorizing of such terms and avoiding errors in their use.

Spelling differences in British and US English: miscellanea

\begin{tabular}{|c|c|}
\hline $\mathrm{Br}$ & US \\
\hline ageing & aging \\
\hline aluminium & aluminum \\
\hline counsellor & counselor \\
\hline defence & defense \\
\hline dependant (noun), dependent (adjective) & dependent \\
\hline equalled & equaled \\
\hline fulfil & fulfill \\
\hline grey & gray \\
\hline intervertebral disc & intervertebral dis $\underline{\mathbf{k}}$ \\
\hline labelled & labeled \\
\hline leucocyte & leukocyte \\
\hline to license (verb), licence (noun) & license (verb and noun) \\
\hline modelled & modeled \\
\hline operating theatre & operating room \\
\hline to practise (verb), practice (noun) & practice (verb and noun) \\
\hline programme & program \\
\hline signalled & signaled \\
\hline sulphur & sulfur \\
\hline
\end{tabular}

Thus, the study of potential difficulties, which Ukrainian medical professionals may face in the process of producing medical discourse in British and American English, is important for developing guidelines to eliminate possible mistakes and avoid misunderstanding in medical communication. It is crucial for medical professionals to be aware of differences in spelling of British and American English so that they are able to produce effective genres of medical discourse, which will be accepted by peer-reviewed journals. The analysis of potential challenges in producing medical discourse in British and American English is an important element for integration of Ukrainian researchers into the world community.

\section{References:}

1. Бєляєва О.М. Функціонально-змістовні та функціонально-стильові характеристики наукових текстів / О. М. Бєляєва // Інновації в освіті, науці та виробництві: матеріали шостої Всеукр. конф., 23-24 квіт. 2009 р. / Полтавськ. ін-т економіки і права вищ. навч. закл. "Відкритий ун-т розвитку людини "Україна". - Полтава : ПІЕП, 2009. - С. 108-110.

2. Лисанець Ю. Типологія мовних помилок у процесі вивчення англійської мови студентами вищих медичних навчальних закладів / Ю. Лисанець, Стриж А. // Нові технології навчання: наук.-метод. зб. - К., 2016. - Вип. 86 (Ч.1). - С. 26-28.

3. Bieliaieva O. M. Grammatical and lexical features of academic writing in English for medical students / O. M. Bieliaieva, Yu. V. Lysanets // Сучасні проблеми гуманітаристики: світоглядні пошуки, комунікативні та педагогічні стратегії: матеріали V Всеукр. наук.-практ. конф. (Рівне, 10 грудня 2015 р.). - Рівне, 2015. - С. 233-235.

4. Bieliaieva O.M. Terminological collocations in medical Latin and English: A comparative study / O.M. Bieliaieva, Yu.V. Lysanets, I.V. Znamenska, I.V. Rozhenko, N.M. Nikolaieva // Wiadomości Lekarskie. - 2017. - 70(1). - P. $139-143$.

5. Bieliaieva O. Latin as a language of international communicative status: Medicine of the 16th-17th centuries / O. Bieliaieva, Yu. Lysanets, M. Melaschenko // Georgian Medical News. - 2017. - 262. - P. 120-124.

6. Bieliaieva O. Paronymy in the sublanguage of medicine (linguistic and linguo-didactic aspects) / O. Bieliaieva, Yu. Lysanets, K. Havrylieva, I. Znamenska, I. Rozhenko, N. Nikolaieva // Georgian Medical News. - 2017. - 271. - P. $144-149$.

7. Lysanets Yu. Stylistic features of case reports as a genre of medical discourse [Електронний pecypc] / Yu. Lysanets, H. Morokhovets, O. Bieliaieva // Journal of Medical Case Reports. - 2017. - 11(83). - Режим доступу до журн.: https://doi.org/10.1186/s13256-017-1247-х

8. Lysanets Yu. The use of Latin terminology in medical case reports: Quantitative, structural, and thematic analysis [Електронний pecypc] / Yu. Lysanets, O. Bieliaieva // Journal of Medical Case Reports. - 2018. - 12(45) - Режим доступу до журн.: https://doi.org/10.1186/ s13256-018-1562-x

9. Lysanets Yu. Lexical and grammar features of academic writing in medical English: Lecture Materials for PhD Students / Yu. Lysanets. - Poltava : "Ukrainian Medical Stomatological Academy", 2017. - 56 p.

10. Morokhovets H.Yu. Developing the professional competence of future doctors in the instructional setting of higher medical educational institutions / H.Yu. Morokhovets, Yu.V. Lysanets // Wiadomości Lekarskie. - 2017. - 70(1). - P. 101-104. 